\title{
Financial Feasibility Analysis of Trigona Honey Bee Business in Banten Province
}

\author{
Elpawati \\ Department of Agribusiness \\ Faculty of Science and Technology State Islamic University \\ Jakarta, Indonesia \\ Email: elpawati@uinjkt.ac.id
}

\begin{abstract}
This research aimed to study the financial feasibility in the Trigona sp honey bee business in Banten Province, by calculating the Net Present Value (NPV), the Net Benefit Cost Ratio (Net B/C), the Internal Rate of Return (IRR), and the Payback Period (PP) from the Trigona sp honey beekeepers in Banten Province. Data types and data collection methods include primary and secondary data from governmental institutions and related departments. This research found the financial feasibility of the honey beekeepers and obtained the average Net Present Value (NPV), i.e. Rp 4.021.848. The NPV $>0$ indicated that business is feasible. The Benefit Cost Ratio (BCR) was 2,84 and the Internal Rate of Return (IRR) was 45,7\% > loan interest, indicated that the Trigona honey bee business in Banten Province is feasible with 2,7 years of investment return time.
\end{abstract}

Keywords: Beekeepers, Financial feasibility, Banten Province

\section{Introduction}

Bee cultivation is an activity that provides added values for plant cultivation. Beekeeping development is considered as important because Indonesia has great potential in this sector. Nature and climate in Indonesia support bee cultivation since the bee forage is available all year round (Septiantina dan Krisnawati, seri iptek V 2015)

According to Septiantina dan Krisnawati (seri iptek V, 2015), Trigona is a species in genus Meliponini, which is classified as stingless bees. The Trigona bees rely on propolis (bee glue) to defend the nest against predators and to maintain the nest temperature. The Trigona cultivation can be found in lowland (beach areas) and upland (mountain areas) and successfully cultivated in all locations.

Trigona are social insects belonging to stingless bees, using flowers as their food source. Trigona mostly live in the nests to protect the nests and to reserve forage, (Inoue dkk,1993). According to Erniwati (2013), there are approximately 50 species of stingless bees in South East Asia. However, the number of stingless bees in Indonesia has not been identified. Schwarz in Erniwati stated there were 31 species of stingless bees in Kalimantan, 41 species in Sumatra and 9 species in Java Island. However, according to stingless bee specialist, Sakagami in Erniwati (2013), there were only 6 species in Java Island, namely Trigona Leaviceps, T. Itama, T. Drescheri, T. Apicalis, T. Thoracia, and T. Terminata. (Sakagami etc., 1990 in Erniwati).

According to the Ministry of Forestry, Indonesia, which has 136,88 million hectares of forest, has high potential honey development. Forest resources may be developed as an ecosystem and honey bee farms. Unfortunately, honey production in Indonesia is still low, therefore Indonesia has to import $70 \%$ of national demand or approximately 3.000 tons of honey per year. Honey production in Indonesia is still low, namely, $1.000-1.500$ tons yearly and $90 \%$ honey production in Indonesia is mainly produced by forest honey bee. Unfortunately, the selling price of Trigona honey in Banten Province is still relatively low, i.e. Rp $400.000 / 600 \mathrm{ml}$; the number of production is $6.57 \mathrm{1} /$ year in average. This situation commonly due to the problems facing by the beekeepers in producing bee honey, such as limited capital, limited capability of the beekeepers in cultivating, and market information.

Based on the background of study and the problems appeared, this research aimed to calculate financial feasibility of Trigona honey bee business in Banten Province. Particularly, this research calculated the Net Present Value (NPV), the Net Benefit Cost Ratio (Net $\mathrm{B} / \mathrm{C}$ ), the Internal Rate of Return (IRR), and the Payback Periode (PP) of the Trigona honey beekeepers in Banten Province.

\section{Method}

Data used in this research includes two types, namely primary and secondary data. Primary data obtained from observation and interview. Secondary data obtained from literature study, papers, and related institutions. Observation, questionnaire distribution, and data collection were carried out by the researchers. This research used Non Probability Sampling Method. According to Sugiyono 2009, Non Probability Sampling Method is a sampling technique that does not provide equal chance for any member of population to be chosen as samples. This research used Saturation Sampling method, which is a 
determining sample technique when all population members used as samples. The calculation of financial feasibility used the interest rate of People Business Credit Program (Kredit Usaha Rakyat) of a State-Owned Bank (BUMN) by $9 \%$. This study considered that the honey bee business in Banten Province is still classified as peopleoriented scale not industry-scale business.

\section{Financial Feasibility Analysis}

Financial Feasibility is one of the aspects of business feasibility study. Husein Umar (2005) stated that the business feasibility study is a research on business plans that does not only analyze the viability of a business when it is creating, but also when a business is operating routinely to achieve the maximum profit in an unlimited period of time. According to Suwinto (2011), feasibility study is a study to examine business feasibility comprehensively and intensively. The feasibility of a business is referring to the comparison results of all economic factors that are allocated in a business/new business and the return of investment in a certain period. The examination of financial aspects is used to calculate the funds needed to create and operate a business and also to study the possibility of the source of funds.

a) The Net Present Value (NPV) is an investment criterion that is commonly used to calculate whether a proposed project is feasible or not. The Net Present Value (NPV) is the Present Value of the difference between benefits and costs on a certain discount rate. NPV calculated the comparison of benefit surplus and cost. The NPV formula is as follows:

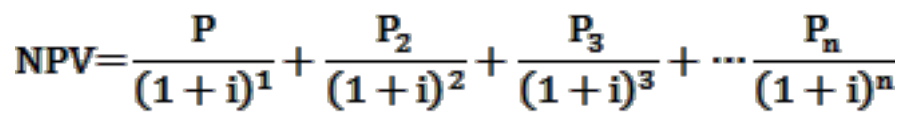

$$
\mathrm{NPV}=\sum_{1}^{\mathrm{n}} \frac{\mathrm{P}_{\mathrm{t}}}{(1+\mathrm{i})^{\mathrm{t}}}-\mathrm{IO}
$$

where:

$$
\begin{aligned}
& \text { Pt } \quad \text { Net cash flow (Proceeds) in the } 1^{\text {st }} \\
& \text { i } \quad=\text { Discount rate } \\
& \text { n = Number of time period of investment } \\
& \text { IO = Initial outlays (initial investment cost) }
\end{aligned}
$$

According to Joel and Jae Shim in Irham Fami: Business is feasible when the present value is positive $(\mathrm{NPV}>0)$ or $(\mathrm{NPV}>1)$. b) Internal Rate of Return (IRR) is a discount rate that makes the net present value of all cash flows from a particular project equal to zero.

$$
\begin{aligned}
& \text { where: } \\
& \text { IRR = Internal rate of return to be required } \\
& \text { IR1 = Internal rate (discount rate) of } \\
& \text { period-1 } \\
& \text { IR2 = Internal rate (discount rate) of } \\
& \text { period-2 } \\
& \text { NPV1 = net present value derived from IR } \\
& \text { NPV2 = net present value derived from IR }
\end{aligned}
$$

According to Suliyanto, a project is feasible if the IRR exceeds a company's required rate of return. The contrary is a project is not feasible when the IRR lower than a company's required rate of return.

c) Net Benefit Cost Ratio is the indicator of net positive discounted benefit $(+)$ versus net negative discounted benefit (-), indicated by formula as follows:

$$
\text { Net } \mathrm{B} / \mathrm{C}=\frac{\sum_{i=1}^{n} \overline{N B}_{i(+)}}{\sum_{i=1}^{n} \overline{N B}_{i}(-)}
$$

A proposed project is feasible if $\mathrm{Net} \mathrm{B} / \mathrm{C}$ is greater than 1 and non-feasible if Net $\mathrm{B} / \mathrm{C}$ is lower than 1 . Cash in flows equal to cash out flows if $\mathrm{Net} B / \mathrm{C}$ equal to 1. In Present. Value it is called Break Even Point (BEP) when total cost is equal to total revenue.

d) Payback Period

Payback Period is a method used to calculate the length of time required to recover the amount invested on annual cash in flows (proceeds) generated by the investment (Suliyanto, 2010).

$$
\text { Payback Period }=\frac{\text { Net Cash Investment }}{\text { Annual Net Cash Inflows }}
$$

\section{Discussion}

Research found that Trigona honey bee business in Banten Province is still classified as a small-scale business with a small amount of capital. This business is not the main job. The maintenance and the packing of products are still moderate. The biggest amount of capital

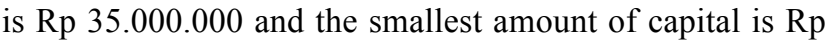
900.000 with the average profit Rp 1.870.400. 
Table 1. The Cash Flow of Trigona Beekepers in A Year

\begin{tabular}{|c|c|c|c|c|c|}
\hline No & Name & Investment & Cost & Revenue & Profit \\
\hline 1 & Epen & Rp900.000 & Rp180.000 & Rp990.000 & Rp810.000 \\
\hline 2 & H. Hamami & Rp3.600.000 & Rp612.000 & Rp1.350.000 & Rp738.000 \\
\hline 3 & Apud & Rp1.260.000 & $\mathrm{Rp} 258.000$ & Rp1.080.000 & Rp822.000 \\
\hline 4 & Ayip & Rp15.000.000 & Rp18.000.000 & Rp22.700.000 & Rp4.700.000 \\
\hline 5 & Mardi & Rp1.710.000 & Rp324.000 & Rp1.080.000 & Rp756.000 \\
\hline 6 & Oji & Rp1.350.000 & Rp324.000 & Rp720.000 & Rp396.000 \\
\hline 7 & Nana & Rp1.980.000 & Rp396.000 & Rp1.170.000 & Rp774.000 \\
\hline 8 & Memed & Rp3.600.000 & Rp720.000 & Rp3.240.000 & Rp2.520.000 \\
\hline 9 & Makmud & Rp3.240.000 & Rp648.000 & Rp1.710.000 & Rp1.062.000 \\
\hline 10 & Uen & Rp1.620.000 & Rp324.000 & Rp1.350.000 & Rp1.026.000 \\
\hline 11 & UstadRohman & Rp2.160.000 & $\mathrm{Rp} 268.000$ & Rp2.160.000 & Rp1.892.000 \\
\hline 12 & Sodikin & Rp1.080.000 & $\mathrm{Rp} 216.000$ & Rp1.170.000 & Rp954.000 \\
\hline 13 & Riyadi & Rp25.000.000 & Rp900.000 & Rp8.000.000 & Rp7.100.000 \\
\hline 14 & H. Pulung & Rp9.000.000 & Rp1.404.000 & $\mathrm{Rp} 4.950 .000$ & Rp3.546.000 \\
\hline 15 & Adhar & Rp3.000.000 & Rp982.000 & Rp2.340.000 & Rp1.358.000 \\
\hline 16 & Anwar & Rp3.240.000 & Rp648.000 & Rp1.440.000 & Rp792.000 \\
\hline 17 & Yadi & Rp2.340.000 & Rp360.000 & Rp990.000 & Rp630.000 \\
\hline 18 & Marno & Rp1.640.000 & Rp288.000 & Rp2.070.000 & Rp1.782.000 \\
\hline 19 & Sajar & Rp2.000.000 & Rp900.000 & Rp1.350.000 & Rp450.000 \\
\hline 20 & Komeng & Rp35.000.000 & Rp6.000.000 & Rp11.300.000 & Rp5.300.000 \\
\hline \multicolumn{2}{|c|}{ Rata-rata } & Rp5.936.000 & Rp1.687.600 & Rp3.558.000 & Rp1.870.400 \\
\hline
\end{tabular}

Source: Data primer diolah, 2017

a) Net Present Value (NPV)

Samples in this research indicated the average NPV, i.e. Rp 4.021.848,- was greater than 0. Therefore, the Trigona honey bee business in Banten Province is feasible.

b) Benefit Cost Ratio (BCR)

The BCR of the average number of the Trigona beekeepers in Banten Province was 2,84, where one rupiah has benefit value 2,84 . Therefore, this business is feasible.

c) Internal rate of return(IRR)

The IRR of the average number of the honey beekeepers in Banten Province was 45,7\% and greater than the present rate interest. Therefore business is feasible.

d) Payback Periode (PP)

This research found the average total return of investment from the beekeepers in honey bee business in Banten Province is 2 years and 7 months.

\section{Conclusion}

The average NPV obtained from feasibility analysis is $\mathrm{Rp}$ 4.021.848,-- The NPV $>0$ indicated that business is feasible. The Benefit Cost Ratio (BCR) 2,84 and the Internal Rate of Return (IRR) 45,7\% > loan interest, indicated that Trigona honey bee business in Banten Province is feasible with 2,7 years of investment return time. It is concluded that the Trigona honey bee business in Banten Province is financially feasible. However, further researches have to be conducted to escalate the productivity of Trigona bee in Banten Province in increasing the number of production produced by the beekeepers.

\section{Reference}

[ 1 ] Dinas Kehutanan dan Perkebunan Provinsi Banten. 2011. Statistik Dinas Kehutanan dan Perkebunan Provinsi Banten Dalam Angka.

[2] Erniawati. 2013. Kajian Biologi Lebah Tak Bersengat (Trigona) di Indonesia, Fauna Indonesia Jurnal Vol 12. Bogor: Bidang Zoologi Puslit Biologi - LIPI. 
[3] industri.bisnis.com, 70\% kebutuhan madu RI dipasok produk impor. Selasa, 12/07/2011 04:53 WIB.

[4] Irham Fahmi. 2012. Manajemen, Teori, Kasus, dan Solusi. Jakarta.

[ 5 ] Johan, Suwinto. 2011. Studi Kelayakan Pengembangan Bisnis. Yogyakarta: Graha

[6] Ilmu.

[7] Kementerian Lingkungan Hidup dan Kehutanan. 2014. Statistik Kementerian Lingkungan Hidup dan Kehutanan Dalam Angka.

[ 8 ] Septiantina D.R dan Krisnawati. 2015. Buku Seri Iptek Kehutanan Seri V.

[9] Sugiyono. 2009. Metode Penelitian Kuantitatif Kualitatif dan R\&D. Bandung: Alfabeta.

[10 ] Suliyanto. 2010. Studi Kelayakn Bisnis. Yogyakarta: Andi Yogyakarta.
[11] Takehiko Kakutani, Tamiji Inoue, Toshiyuki Tezuka, and Yasuo Maeta. 1993. Pollination of Strawberry By The Stingless Bee, Trigona Minangkabau, and The Honey Bee, Apis Mellifera: an Experimental Study of Fertilization Efficiency. Society of Population Ecology. 35: 95-111.

[12] Tamiji Inoue, Shoichi F Sakagami, Siti Salmah, and Soichi Yamane. 1984. The Peocess of Colony Multiplication in the Sumatra Stingless Bee Trigona Leaviceps. Biotropica. 16: 100-111.

[13 ] Teruyoshi Nagamitsu, Kumiyasu Momose, Tamiji Inoue, and David W. Roubik. 1999. Preference in Flower Visits and Partitioning in Pollen Diets of Stingless Bees in an Asian Tropical Rain Forest. Res Popul Ecol. 41: 195-202. 